\title{
Performance of organic grain legumes in Tuscany
}

\author{
Valentina Moschini, ${ }^{1}$ Giovanna Casella, ${ }^{1}$ Roberto Vivoli, ${ }^{1}$ Concetta Vazzana, ${ }^{1}$ \\ Andrea Martini, ${ }^{1}$ Claudia Lotti, ${ }^{1}$ Paola Migliorini ${ }^{2}$ \\ 'Department of Agrifood and Environmental Sciences, University of Florence, Italy; \\ ${ }^{2}$ University of Gastronomic Sciences, Bra (CN), Italy
}

\begin{abstract}
In 2005-2007 growing season, few varieties of field bean, high protein pea and white lupin were compared in an organic farm of Central Italy (Mugello area, Tuscany), to evaluate their agronomic performance in terms of grain yield, nutritional quality and competitive ability against weeds. The experiment was performed under rain-fed conditions. Furthermore, grain legumes features were compared between two different sowing seasons (autumnal $v$ late-winter) for two years, in order to get information on the best time of sowing of these species, and the stability of yields of different genotypes in those climatic and soil conditions. These legumes could be an alternative protein source to external soybean, a high-risk alimentary source of genetically modified organisms, in the organic livestock sector. The main findings indicate that higher yields in grain and crude protein were obtained with the pea species and in particular with cultivars Hardy (4.0 t/ha grain yield; $626 \mathrm{~kg} / \mathrm{ha}$ crude protein yield) and Classic (3.1 tha grain yield; $557 \mathrm{~kg} / \mathrm{ha}$ crude protein yield); followed by field bean cv. Chiaro di Torre Lama (2.9 t/ha grain yield; $624 \mathrm{~kg} / \mathrm{ha}$ crude protein yield) and cv. Vesuvio (2.5 t/ha grain yield; $549 \mathrm{~kg} / \mathrm{ha}$ crude protein yield). Furthermore the field bean is interesting for the stability of yield in both years despite climatic conditions rather different. The white lupin has showed the lower yield but the best values of grain quality, with higher values in lupin Multitalia for dry matter, crude protein and ether extract and in lupin Luxe also for crude fibre,
\end{abstract}

Correspondence: Paola Migliorini, University of Gastronomic Sciences, Piazza Vittorio Emanuele 9, Frazione Pollenzo - 12042 Bra (CN), Italy.

E-mail: p.migliorini@unisg.it

Key words: organic farming, grain legumes, field bean, high protein pea, white lupin, Mediterranean crops.

Acknowledgments: this study was carried out in the framework of the EQUIZ00BIO (http://www.equizoobio.it) research project, funded by Marche Region.

Received for publication: 15 April 2013.

Revision received: 23 December 2013.

Accepted for publication: 4 January 2014.

CC Copyright V. Moschini et al., 2014

Licensee PAGEPress, Italy

Italian Journal of Agronomy 2014; 9:525

doi:10.4081/ija.2014.525

This article is distributed under the terms of the Creative Commons Attribution Noncommercial License (by-nc 3.0) which permits any noncommercial use, distribution, and reproduction in any medium, provided the original author(s) and source are credited. respect to the other legumes analysed. Among lupin varieties, lupin Multitalia showed the best yield results for the pedo-climatic conditions of Mugello area ( 0.9 t/ha lupin Multitalia; 0.2 t/ha lupin Luxe). The total yield of organic grain legumes, in the experimental site, is resulted higher with an autumnal seeding respect to the late-winter seeding (2.8 t/ha vs $1.9 \mathrm{t} / \mathrm{ha})$.

\section{Introduction}

There are 1.8 million farmers in 162 countries growing organically on more than 37 million hectares of agricultural land worldwide. The global market for organic food reaches US $\$ 62.9$ billion, which is an increase of US $\$ 4$ billion compared to the previous year (Willer et al., 2013), mainly because of their reputation as being environmentallyfriendly and healthy products. In Italy 1,167,362 hectares of farmland are organically managed, employing 49,709 operators (SINAB, 2013), with an increase trend (respectively $+6 \%$ and $+3 \%$ of 2012 ), compared with a not positive tendency of primary sector in general (Mipaaf, 2012a). However, the livestock sector shows great instability, in particular the cattle one. The problem faced by organic livestock farmers is the supply of feed certificated genetically modified organisms (GM0)-free, with affordable and stable costs (Mordenti and De Castro, 2005; Mipaaf, 2012a).

Indeed, though its ancient traditions in central and south Italy the cultivation of grain legumes has undergone significant contraction in the last forty years (Ranalli, 2001), to the benefit of crops more profitable and/or more subsidized (i.e. corn). These trends have led Italy to be largely dependent on grain imports. The amount of organic soybean imported in Italy ( $85 \%$ from Asia) in 2011 was 20.187 ton (SINAB, 2013) with high risk of GMO contamination (Nowack et al., 2002). Moreover, in organic animal husbandry, the low availability of certified organic grain legumes increased the cost of this input and could cause problems in economic sustainability of those farms. Furthermore, the recent amendment of Regulation (EC) No. 889/2008 (Commission Implementing Regulation (EU) No. 505/2012) requires that at least $60 \%$ of the feed ( $20 \%$ in case of pigs and poultry) has to come from the farm unit itself or in case this is not feasible, has to be produced in cooperation with other organic farms in the same region (European Commission, 2008, 2012).

The production of soybean in the Italian area is conditioned by the availability of water, which makes this crop not suitable for all farm situations, especially in rain-fed farming condition of central-south Italy (Bonciarelli and Bonciarelli, 2001).

Grain legumes such as field bean (Vicia faba L var. minor), high protein pea (Pisum sativum L.) and white lupin (Lupinus albus L.) play a fundamental role in organic agriculture and livestock (Siddique et al., 1999) to improve soil fertility (Unkovich et al., 1997; Van Kessel and Hartley, 2000; Ranalli, 2001; Badgley et al., 2007), to close the cycle of nitrogen (Unkovich et al., 2000; Pang and Letey, 2000; Jensen 
et al., 2010; Köpke and Nemecek, 2010) and as protein sources alternative to soybean (Froidmont and Bartiaux, 2004; Jezierny et al., 2010 ), which could reduce the risk of GMO contamination in the food chain.

Even though protein pea and field bean are mainly diffused in Italy as grain legumes for animal feeding, recently there is an increasingly curiosity for white lupin (Lupinus albus L.). This legume crop indeed recorded interesting performances about high protein content (that can vary from $34.6 \%$ to $43.2 \%$ ) and fat content (10\% on average) in different countries (i.e. France, Spain, Germany and Australia). In particular the fat content resulted to be much higher than other leguminous crops (Innocenti and Dal Re, 2007). In Italy lupin (spp.) cultivation decreased from 60,000 hectares in the thirties (1931-35) to 3000 hectares in the late eighties (1986-1990). Contrary, in the same period, the seed production moved from $0.93 \mathrm{t}^{\text {-ha }}$ to $1.27 \mathrm{t}^{\text {-ha }}$ (Fagnano and Bozzini, 2001). The negative trend was mainly due to toxic alkaloids and anti-nutritional factors contained in different species like yellow (Lupinus luteus L.) and blue lupin (Lupinus angustifolius L.) that decreased interest in this crop for human nutrition and for animal feeding. At present, only one white lupin variety (Multitalia) is enrolled in the national registry (Mipaaf, 2012b). Nevertheless, the cultivation of white lupin can gain a renewed interest, due to commercial availability of new varieties and to the enforcement of EU support regime. Compared with other leguminous crops, lupin species are conditioned by specific soil characteristics. In fact, the white lupin well adapts to silt loam or loam soil, poor in lime which inhibits its specific rhizobium (Bradyrhizobium lupini), causing phenomena of chlorosis, with acid reaction (Lupinus albus tolerate a pH up to 7.2) and well drained (the plant appears sensitive to stagnant water and root asphyxiation).

In the few genetic improvement programs developed at Italian national level on protein crops, the variety comparison of grain legumes is an activity that could promote a product innovation. The purpose of this research was to assess, in a farm under the organic production regulation [Reg EU 834/2007 (European Commission, 2007); Reg EU 889/2008 (European Commission, 2008)], both: i) the adaptability of few varieties of legumes crop (field pea, field bean and white lupin) to climatic and soil conditions of Mugello basin, an area located in the northern part of the Tuscany Region (Italy); ii) the agronomic performances (grain yield and quality, competition against weeds) related to the seeding season (autumnal and late-winter); in order to asses the alternative to soybean cultivated under irrigated conditions or purchased.

The Mugello area has a great tradition in livestock farming. Already in $5^{\text {th }}$ century, The Medici family in their farm in this area, bred cows for their use and for trade. Even today, after centuries, the Mugello keeps this vocation and there are many livestock farms of cattle, sheep and pigs in the area, many of which are organic: 39\% of livestock farms of Florence's province are in Mugello area and 27.12\% of utilized agricultural area it's organic (PLSR, 2009). In particular: i) cow's milk is intended largely to the population of Florence with a production of high quality or organic milk; ii) sheep's milk is worked partly by shepherds becoming excellent pecorino cheese; iii) beef, pork and lamb is marketed through the capillary network of the butchers in the area.

\section{Materials and methods}

The research was carried out in 2005-2007 in an organic dairy farm of Tuscany (Borgo San Lorenzo, Florence, $193 \mathrm{~m}$ asl). The experimen-
Table 1. Main characteristics of soil.

\begin{tabular}{lc} 
Characteristic & Value \\
Sand (\%) & 7 \\
Silt (\%) & 28 \\
\hline Clay (\%) & 65 \\
$\mathrm{pH}$ & 6.86 \\
\hline $\mathrm{N}$ total (\%) & 1.21 \\
$\mathrm{P}_{2} \mathrm{O}_{5}$ avail. (ppm) & 150.60 \\
\hline $\mathrm{K}_{2} \mathrm{O}$ exchang. (ppm) & 351 \\
Ca exchang. (ppm) & 2321 \\
\hline Organic matter (\%) & 1.67 \\
\hline
\end{tabular}

tal site was located in a part of the farm characterized by flat fields. The soil is classified as Typic Udifluvents (Sanesi, 1977) and it has been created from fluvial deposits of Sieve river. Texture characteristics place the soil in a clay soil. Main soil physical and chemical properties are reported in Table 1. The crop rotation is the following: maize - pea - barley - maize - alfalfa 3 years. The preceding crop to our experimental cultivation of grain legumes was maize in both years.

The experiment was performed under rain-fed conditions. The climate in experimental area is continental (Table 2). In particular winter 2005/2006 was characterized by temperature more severe and colder than the long-term mean with a long freeze-up period; while the winter 2006/2007 was characterized by low precipitation and higher temperature compared to long-term mean.

The seven varieties ( 2 of field bean, 3 of field pea and 2 of white lupin) of Italian and French origin used in both years are listed in Table 3.

The field trial was laid out in a randomized block design with two replicates. Plots size was $1200 \mathrm{~m}^{2}(6 \times 200 \mathrm{~m})$. The experimental plots were ploughed ( $35 \mathrm{~cm}$ deep) on 28 September 2005 and 15 September 2006 and then they were honed with a rotating harrow joined to the seeder at sowing time. Sowing was executed on 22 November 2005 and 13 November 2006 (autumn sowing) and 6 February 2007 (latewinter sowing), with the plant density reported in Table 3 and without fertilization. White lupin seeds were inoculated with Bradyrhizobium lupins (souche LL13). In winter 2005 white lupin crops have endured strong damages from winter cold (Table 2) and a spring seeding of white lupin has been necessary on 3 April 2006. The presence and density of weeds (number of species and number of individuals for each species) was determined on 6 April 2006 and 9 May 2007 with two samplings of $0.25 \mathrm{~m}^{2}$ within each plot. Furthermore for weeds was calculated the Shannon index (Shannon and Weaver, 1963), whose value depends on the species richness and the distribution of individuals among species (Pielou, 1966).

On 26 June 2006 and 9 May 2007 the average plant height was assessed. Seeds were harvested on 26 June for all varieties, in both years, with 3 samplings of $1 \mathrm{~m}^{2}$ within each plot, except for white lupin with spring sowing in 2006 that was harvest on 14 July 2006. Mechanical harvesting was performed when grain reached $13 \%$ of relative humidity.

Quality of grains were assessed with chemical analysis to determine dry matter (DM), crude protein, fat, crude fibre, ash according with AOAC methodology (AOAC, 1990) and fibrous fraction (NDF, ADF, ADL) according with Van Soest (Van Soest et al., 1991).

Differences between treatments were tested using an analysis of variance (ANOVA) and mean comparisons were evaluated by the Bonferroni test (SPSS; Stata Corp., College Station, TX, USA). 


\section{Results}

\section{Competitive ability against weeds}

The analysis of variance (ANOVA) for the variables number of weeds, number of weeds species and Shannon index for the factors species variety and seeding season, as showed in Table 4, do not present statistical significance differences of the variables analysed in function of legume species and seeding time.

\section{Grain yield and nutritional quality}

Significant differences emerge among the species and varieties in relation to morphological and productive parameters.

For the factor height of legume plants the ANOVA highlights a statis-

Table 2. Monthly precipitation, average daily, minimum temperature, number of freezing days and ice days at the experimental site (Borgo San Lorenzo, Florence, Italy; Source: http://www.giottoulivi.it/Meteo.asp; http://www.ilmeteo.it/portale/archiviometeo/Borgo+San+Lorenzo/2007/Maggio).

\begin{tabular}{|c|c|c|c|c|c|c|}
\hline & & mean & & Departure & term mean & \\
\hline & ${ }^{\circ} \mathrm{C}$ & mm/month & $2005 / 06\left({ }^{\circ} \mathrm{C}\right)$ & $\mathrm{mm} / \mathrm{month}$ & $2006 / 07\left({ }^{\circ} \mathrm{C}\right)$ & mm/month \\
\hline November & 9.2 & 142 & -2.41 & 16.2 & -0.43 & -59.19 \\
\hline December & 5.1 & 110 & -2.16 & 11 & 0.88 & -50.55 \\
\hline January & 4.3 & 96 & -2.44 & -8.4 & 3.86 & -62.99 \\
\hline February & 5.8 & 99 & -1.50 & -26.6 & 4.3 & -13.92 \\
\hline March & 8.7 & 91 & -1.56 & 51.8 & 3.1 & -63.05 \\
\hline April & 12.3 & 88 & 0.67 & -60.6 & 4.7 & -80.89 \\
\hline May & 16.3 & 79 & -0.12 & 31.8 & 2.9 & -4.59 \\
\hline June & 20.3 & 58 & -0.53 & -23.71 & 2.4 & -32.6 \\
\hline July & 22.8 & 30 & 1.09 & -23.9 & 2.7 & -30 \\
\hline August & 22.5 & 53 & -2.32 & 4.4 & 1 & 63.59 \\
\hline September & 19.2 & 88 & -0.83 & -59.1 & 0.5 & -33.39 \\
\hline October & 14.2 & 118 & 0 & -80.15 & 1.9 & -68.72 \\
\hline Mean & 13.39 & 1052 & -1 & -167.3 & 27.8 & -436.3 \\
\hline Minimum temperature & & & -9.7 & & -3 & \\
\hline Date & & & 30 December & & 27 December & \\
\hline Freezing days* & & & 43 & & 13 & \\
\hline Ice days $^{\#}$ & & & 0 & & 0 & \\
\hline
\end{tabular}

*Days with a minimum temperature under $0^{\circ} \mathrm{C}$ between November and March; ${ }^{\sharp}$ days with a maximum temperature under $0^{\circ} \mathrm{C}$ between November and March.

Table 3. Characteristics of the varieties of legumes crops used in the experiment.

\begin{tabular}{|c|c|c|c|c|}
\hline Species & Variety & Constitutor & $\begin{array}{l}\text { Seed density } \\
\left(\text { seeds } / \mathrm{m}^{2}\right)\end{array}$ & $\begin{array}{c}\text { Distance } \\
\text { between rows }(\mathrm{cm})\end{array}$ \\
\hline Vicia faba L var. minor & $\begin{array}{l}\text { Vesuvio } \\
\text { Chiaro di Torre Lama }\end{array}$ & $\begin{array}{l}\text { Iscf/SIS } \\
\text { Università di Napoli/ Agroservice }\end{array}$ & $\begin{array}{l}50 \\
50\end{array}$ & $\begin{array}{l}18 \\
18\end{array}$ \\
\hline Pisum sativum L. leafless type & $\begin{array}{l}\text { Classic } \\
\text { Hardy } \\
\text { Ideal }\end{array}$ & $\begin{array}{l}\text { Cebeco } \\
\text { Serasem/Florisem } \\
\text { Serasem/SIS }\end{array}$ & $\begin{array}{l}100 \\
100 \\
100\end{array}$ & $\begin{array}{l}18 \\
18 \\
18\end{array}$ \\
\hline Lupinus albus $L$. & $\begin{array}{l}\text { Multitalia } \\
\text { Luxe }\end{array}$ & $\begin{array}{l}\text { Università di Napoli/ Agroservice } \\
\text { Inra-AgriObtentions/ Jouffrey Drillaud }\end{array}$ & $\begin{array}{l}50 \\
50\end{array}$ & $\begin{array}{l}36 \\
36\end{array}$ \\
\hline
\end{tabular}

Table 4. Effect of species variety and seeding season on number of weeds $\left(\mathbf{n} / \mathrm{m}^{2}\right)$; number of weed species $\left(\mathbf{n} / \mathrm{m}^{2}\right)$ and $S h a n n o n$ index.

$\begin{array}{lccc} & \text { Weed plant }\left(\mathrm{n} / \mathrm{m}^{2}\right) & \text { Weed species }\left(\mathrm{n} / \mathrm{m}^{2}\right) & \text { Shannon index } \\ \text { Species variety }(\mathrm{V}) & & \text { n.s. } & \text { n.s. } \\ \text { Field bean Chiaro torre lama } & \text { n.s. } & 8.9 & 1.5 \\ \text { Field bean Vesuvio } & 224.7 & 9.4 & 1.4 \\ \text { Lupin Luxe } & 186.2 & 7.4 & 1.2 \\ \text { Lupin Multitalia } & 133.7 & 7.9 & 1.1 \\ \text { Pea Classic } & 127.7 & 10.1 & 1.7 \\ \text { Pea Hardy } & 158.7 & 10.6 & 1.5 \\ \text { Pea Ideal } & 213.2 & 9.9 & 1.4 \\ \text { Seeding season (S) } & 204.7 & \mathrm{n} . \mathrm{s} & \mathrm{n} \\ \text { Autumnal } & \text { n.s. } & 9.0 & 1.3 \\ \text { Late-winter } & 176.7 & 9.3 & 1.5\end{array}$

Error

16

n.s., not significant. 
tical significant result for the variables species variety and interaction species variety (V) for seeding season (S) (Table 5). Lupin Luxe (26.7 $\mathrm{cm}$ ) showed the lesser value in terms of plant height compared to lupin Multitalia $(75.5 \mathrm{~cm})$ and to the others species.

In relation to interaction species variety for seeding season, only field bean Chiaro di Torre Lama showed a highest value in term of height

Table 5. Average height $(\mathrm{cm})$ in function of species variety and seeding season.

\begin{tabular}{lc} 
& $\begin{array}{c}\text { Legume height } \\
(\mathrm{cm})\end{array}$ \\
Species variety (V) & $* *$ \\
1. Field bean Chiaro torre lama & $105.7^{\mathrm{a}}$ \\
2. Field bean Vesuvio & $95.8^{\mathrm{ab}}$ \\
3. Lupin Luxe & $26.7^{\mathrm{d}}$ \\
4. Lupin Multitalia & $75.5^{\mathrm{c}}$ \\
5. Pea Classic & $87.6^{\mathrm{bc}}$ \\
6. Pea Hardy & $78.7^{\mathrm{c}}$ \\
7. Pea Ideal & $78.7^{\mathrm{c}}$ \\
Seeding season (S) & $n . .^{\mathrm{c}}$ \\
1. Autumnal & $80.6^{\mathrm{c}}$ \\
2. Late-winter & $76.2^{\mathrm{a}}$ \\
\hline Interaction V*S & $* *$ \\
1-1 & $122.5^{\mathrm{a}}$ \\
1-2 & $88.8^{\mathrm{bc}}$ \\
2-1 & $107.4^{\mathrm{b}}$ \\
2-2 & $84.1^{\mathrm{bc}}$ \\
3-1 & $27.0^{\mathrm{d}}$ \\
3-2 & $26.5^{\mathrm{d}}$ \\
4-1 & $70.5^{\mathrm{c}}$ \\
4-2 & $80.5^{\mathrm{c}}$ \\
5-1 & $80.6^{\mathrm{c}}$ \\
6-1 & $94.5^{\mathrm{bc}}$ \\
6-2 & $78.8^{\mathrm{c}}$ \\
$7-1$ & $78.7^{\mathrm{c}}$ \\
E-2 & $77.4^{\mathrm{c}}$ \\
\hline
\end{tabular}

${ }^{* *}$ Significant for $\mathrm{P} \leq 0.01$; n.s. not significant. ab,c,dValues in row followed by different letters are significantly different as determined by the Bonferroni test. plant, in blocks with autumnal seeding $(122.48 \mathrm{~cm})$ compared to those with late-winter seeding $(88.8 \mathrm{~cm})$.

The results of grain legumes yield and their nutritional quality are shown in Table 6. The data of lupin Luxe yield in 2006 it's not available due to the late sowing that compromised the harvest that year. The analysis of variance (ANOVA) of the yields in both years highlighted a higher yield in pea Classic (3.1 t/ha) and pea Hardy (4.0 t/ha) compared to both lupin varieties ( 0.2 t/ha Luxe; 0.9 t/ha Multitalia). Also total grain yield resulted higher with an autumnal seeding $(2.8 \mathrm{t} / \mathrm{ha})$ respect to the late-winter seeding (1.9 t/ha).

For the nutritional properties of grain legumes analysed, it resulted that both kind of white lupin show the highest value of dry matter (96.4\% lupin Luxe; $96.1 \%$ lupin Multitalia) and crude protein $(27.0 \%$ lupin Luxe; $27.6 \%$ lupin Multitalia). Although, only the lupin Multitalia shows a higher value of ash content (5.9\%) compared to the other grain legumes analysed. Furthermore the grain's dry matter shows a higher value in autumnal seeding time (94.9\%) that in late-winter time (94.3\%).

The crude protein (\%DM) shows a decreasing value from lupin's variety, followed by field bean Vesuvio (21.1\%) and then from pea Classic (17.0\%) and Hardy (17.2\%) that are respectively statistically different.

The value of crude protein yield is instead lower in lupin Luxe (47 $\mathrm{kg} / \mathrm{ha}$ ) and lupin Multitalia (205 kg/ha) that in the other species, not statistically different each other.

The ether extract (\%DM) show the highest value in lupin Luxe grain (2.9\%), followed by lupin Multitalia (2.1\%) respect to all the other species that have a lower value.

Lupin Luxe shows instead a high value of crude fibre (16.4\%) compared to pea Hardy (7.6\%). Only the ADL fibrous fraction has a significance statistical value with a higher concentration in field bean Vesuvio $(4.4 \%)$ that in all three varieties of pea (pea Classic $0.6 \%$; pea Hardy $0.8 \%$; pea Ideal $1.1 \%$ ).

\section{Discussion and conclusions}

The analysis of variance for the variables related to weed presence and their biodiversity it is not resulted statistically significant, but the

Table 6. Average grain yield (t/ha) of both growing season at $13 \%$ of humidity and value of quality parameters.

\begin{tabular}{|c|c|c|c|c|c|c|c|c|c|c|}
\hline & $\begin{array}{c}\text { Grain yield average } \\
\text { t/ha }\end{array}$ & $\begin{array}{l}\text { DM } \\
\%\end{array}$ & $\begin{array}{l}\text { Ash } \\
\% \mathrm{DM}\end{array}$ & $\begin{array}{c}\text { CP } \\
\text { \%DM }\end{array}$ & $\begin{array}{l}\text { CP yield } \\
\text { kg/ha }\end{array}$ & $\begin{array}{l}\text { EE } \\
\% \mathrm{DM}\end{array}$ & $\begin{array}{c}\mathrm{CF} \\
\% \mathrm{DM}\end{array}$ & $\begin{array}{l}\text { NDF } \\
\% \text { DM }\end{array}$ & $\begin{array}{l}\text { ADF } \\
\% \mathrm{DM}\end{array}$ & $\begin{array}{l}\text { ADL } \\
\% D M\end{array}$ \\
\hline Species variety (V) & $* *$ & $* *$ & $* *$ & $* *$ & $* *$ & $* *$ & $* *$ & n.s. & n.s. & $* *$ \\
\hline Field bean Chiaro T.L. & $2.9^{\mathrm{ab}}$ & $93.8^{b}$ & $4.0^{\mathrm{b}}$ & $20.7^{\mathrm{bc}}$ & $624^{\mathrm{a}}$ & $0.4^{\mathrm{c}}$ & $11.9^{\mathrm{ab}}$ & 33.9 & 17.2 & $2.6^{\mathrm{ab}}$ \\
\hline Field bean Vesuvio & $2.5^{\mathrm{ab}}$ & $93.7^{\mathrm{b}}$ & $3.9^{\mathrm{b}}$ & $21.1^{\mathrm{b}}$ & $549^{a}$ & $0.4^{c}$ & $15.5^{\mathrm{ab}}$ & 33.7 & 23.4 & $4.4^{\mathrm{a}}$ \\
\hline Lupin Luxe & $0.2^{\mathrm{b}}$ & $96.4^{\mathrm{a}}$ & $4.0^{\mathrm{b}}$ & $27.0^{\mathrm{a}}$ & $47^{b}$ & $2.9^{\mathrm{a}}$ & $16.4^{\mathrm{a}}$ & 27.8 & 21.0 & $3.5^{\mathrm{ab}}$ \\
\hline Lupin Multitalia & $0.9^{b}$ & $96.1^{\mathrm{a}}$ & $5.9^{\mathrm{a}}$ & $27.6^{\mathrm{a}}$ & $205^{b}$ & $2.1^{b}$ & $15.2^{\mathrm{ab}}$ & 30.1 & 21.2 & $3.1^{\mathrm{ab}}$ \\
\hline Pea Classic & $3.1^{\mathrm{a}}$ & $94.2^{b}$ & $3.4^{\mathrm{b}}$ & $17.1^{\mathrm{c}}$ & $557^{\mathrm{a}}$ & $0.6^{\mathrm{c}}$ & $8.4^{\mathrm{ab}}$ & 31.6 & 13.4 & $0.6^{b}$ \\
\hline Pea Hardy & $4.0^{\mathrm{a}}$ & $93.7^{\mathrm{b}}$ & $3.5^{\mathrm{b}}$ & $17.2^{\mathrm{c}}$ & $626^{\mathrm{a}}$ & $0.6^{\mathrm{c}}$ & $7.6^{\mathrm{b}}$ & 32.9 & 15.3 & $0.8^{\mathrm{b}}$ \\
\hline Pea Ideal & $2.7^{\mathrm{ab}}$ & $94.4^{b}$ & $3.5^{\mathrm{b}}$ & $18.7^{\mathrm{bc}}$ & $542^{\mathrm{ab}}$ & $0.6^{\mathrm{c}}$ & $8.6^{\mathrm{ab}}$ & 31.3 & 13.4 & $1.1^{\mathrm{b}}$ \\
\hline Seeding season (S) & $*$ & $* *$ & n.s. & n.s. & n.s. & n.s. & n.s. & n.s. & n.s. & n.s. \\
\hline Autumnal & $2.7^{\mathrm{a}}$ & $94.9^{\mathrm{a}}$ & 4.0 & 21.0 & 464 & 1.1 & 11.1 & 31.3 & 17.0 & 2.2 \\
\hline Late-winter & $1.9^{\mathrm{b}}$ & $94.3^{b}$ & 4.0 & 21.6 & 436 & 1.1 & 12.8 & 32.0 & 18.7 & 2.4 \\
\hline Error & 36 & 25 & - & - & - & - & - & - & - & - \\
\hline
\end{tabular}

DM, dry matter (\%); ash (\%DM); CP, crude protein (\%DM); CP yield, crude protein yield (t/ha); EE, ether extract (\%DM); CF, crude fibre (\%DM); NDF, ADF, ADL, fibrous fraction in function of species variety and seeding season. **Significant for $\mathrm{P} \leq 0.01$; * significant for $\mathrm{P} \leq 0.05$; n.s. not significant. a,b,cValues in row followed by different letters are significantly different as determined by the Bonferroni test. 
average number of weed plants for each crops variety (Table 4) it is in line with other experiments on field bean in Tuscany (Barberi et al., 2004) and pea (Lundkvist, 2009) in organic farming systems and white lupin (Carruthers et al., 2008) in conventional one.

The number of weeds seems not to affect the yield of the field pea and field bean, which are in line with the yields expected. In fact, these crops are quite competitive against weeds and, in particular, the field bean has a minimum critical period of weed control (Frenda et al., 2013) and both field bean and pea have a great capacity of soil cover (Tavoletti et al., 2004). This aspect makes these crops particularly interesting for organic cultivation.

In relation to growth of plants, it is possible to note a lower height of lupin Multitalia respect to the standard cultivar characteristic (Agroservice, 2012) in conventional agriculture. A result even lower respect to the standards of cultivar (Arvalis, 2010) was obtained for lupin Luxe. These results make suppose a difficult adaptation of lupin Luxe to soil and climatic condition of Mugello area, irrespective of sowing times, as shown in Table 4. Field bean shown a higher value of plant's height in autumnal sowing, respect to late winter sowing, in agreement with results obtained by other authors (Husain et al., 1988; Duzdemir and Ece, 2011). In the case of pea and lupin species, there is no effect on plant's height in relation to sowing season. This is in agreement with other results obtained in Central Italy for protein pea (Dal Re et al., 2005) but not for white lupin, that usually in autumnal sowing produces taller plants (Postiglione, 1986).

The best performance in yield is harvest by pea Hardy and pea Classic, that show a better adaptability to the climatic and soil conditions of Mugello, with yield results that are in line with other Italian studies (Annicchiarico et al., 2003; Monotti et al., 2004).

The total yield of organic grain legumes analysed resulted higher with autumnal seeding, respect to late-winter seeding; this is in agreement with results obtained by other authors for field bean (Foti, 1989; Stringi, 1994; Battini et al., 2001), white lupin (Postiglione, 1986) and pea varieties low temperature resistant (Ranalli and Parisi, 2001). Similarly, the dry matter content was higher in grain with autumnal seeding, due to a longer biological cycle (Foti et al., 2001). This result implies an advantage for the farmer due to a higher energy content of the feeding grains and possibly a longer shelf life due to less water content.

In relation to the variability of climatic condition, the field bean yield was less influenced by lower winter temperature (2005/2006) and lower precipitation (2006/2007) than the others species analysed, keeping a stable yield in both years. This result highlights that the rainfall averages and dates of sowing are suitable with field bean requirements. Otherwise as Stock (1977) noted, a water stress, at all phenological levels, would produce yield decrease, as well as low temperatures after the plant's phenological level of 4-5 leaves (Bonciarelli and Bonciarelli, 2001). Furthermore, the protein pea cultivars analysed looks more influenced in yield by low precipitation and high temperature averages in $2006 / 2007$ (2.2 t/ha) instead that by lower winter temperatures in Mugello area in 2005/2006 (4.7 t/ha), that were lethal for lupin. This result is in line with features of the pea species as reported by Bonciarelli and Bonciarelli (2001).

The legumes crop lupin, shows the best value of the analysis of grain quality respect to the other species studied. Lupin has the highest value in dry matter, ash, crude protein, ether extract and crude fibre, in agreement with other authors (Degussa, 2006; Jezierny et al., 2007; Jezierny et al., 2010). In particular the two cultivars of lupin stand out each other for a higher value of ash in lupin Multitalia, and a higher value of ether extract in lupin Luxe.

Unfortunately, the high quality performance of lupin it's not support by a high average yield, in this area, so the value of crude protein yield is about the half of the other species. Anyway, the crude protein yield in field bean and field pea doesn't diverge between them, since the higher crude protein percentage in field bean grain, balance the lower field bean yield. These results are in good agreement with results obtained in Marche region in experiments carried out in 2002-2003, under organic farming approach (Tavoletti et al., 2004).

The performance of these grain legumes may be helpful in solving the problem of GMO contamination because the yields of these crops are promising if compared to soya cultivated in marginal areas, or in farms without agronomic condition suitable for soya cultivation, or in farms where no irrigation could be provided.

In confirmation of this, in 2005/06 in order to have comparison data of organic soya bean, cultivated in two adjacent fields of the same farms but irrigated, as necessary for this crop at the climatic conditions of the zone, the yields of two soya bean varieties (Riger and PR92B63) were assessed. They were sowed in May and harvested in September. Yield data were collected with three samplings of $1 \mathrm{~m}^{2}$ each. The values of soya bean yields under irrigated area, in that year in 2005/06 for the varieties Riger and PR92B63 (3.8 and 4.8 tha respectively) were not dissimilar from yields of the field bean and field pea cultivated under rain-fed condition in the same pedo-climatic area and year (data not shown).

In conclusion, the analysis of the performance of organic grain legumes in Mugello area, highlights as field pea cultivars Hardy and Classic are crops of great interest to the production of grain supplies for feeding livestock in organic farming systems in rain-fed conditions, with a higher value of crude protein yield than the other crops; followed by field bean cv. Chiaro di Torre Lama and cv. Vesuvio. Furthermore the field bean is interesting for the stability of yield in both years despite climatic conditions rather different. The lupin has showed the lower yield but the best values of grain quality. Among lupin varieties, lupin Multitalia showed the best yield results for the pedo-climatic conditions of Mugello area.

\section{References}

Agroservice, 2012. Catalogue seed. Available from: http:/www.agroservicespa.it/db/pdf/CatalogoIT_1.pdf Accessed: 25 Feb 2013.

Annicchiarico P, Iannucci A, Filippi L, 2003. Cultivar di colture proteiche a confronto in areali contrastanti. Informatore Agrario 42:73-6.

AOAC, 1990. Official method of analysis. 15th Ed. Association of Official Analytical Chemists, Washington, DC, USA.

Arvalis-Unip, Istitut du vegetal-Interprofession des protéagineux. 2010. Variétés de protéagineux. Pois, Féverole, lupin. Edition Mai 2010 Version informatique, p 12. Available from: http:/www.unip.fr/ uploads/media/Catalogue_varietes_Arvalis-Unip_2010_01.pdf

Badgley C, Moghtader J, Quintero E, Zakem E, Chappell MJ, AvilésVázquez K, Samulon A, Perfecto I, 2007. Organic agriculture and the global food supply. Renew. Agric. Food Sys. 22:86-108.

Barberi P, Belloni P, Cerrai D, Fontanelli M, Moonen AC, Raffaelli M, 2004. Cultural weed control in organic pigeon bean (Vicia faba L. var. minor) through optimisation of crop spatial arrangement. pp 2-7 in Proc. 6th EWRS Workshop on Physical and Cultural Weed Control Lillehammer, Norway.

Battini F, Ligabue M, Marmo N, 2001. Pisello proteico e favino da granella, alternative per soia e farine proteiche. Informatore Agrario, 14:61-5.

Bonciarelli F, Bonciarelli U, 2001. Coltivazioni erbacee. Calderini Ed., Bologna, Italy, p 239.

Carruthers K, Fe Q, Cloutier D, Smith DL, 1998. Intercropping corn with soybean, lupin and forages: Weed control by intercrops combined with interrow cultivation. Eur. J. Agron. 8:225-38.

Dal Re L, Innocenti A, Reggiani R, 2005. Confronti varietali su pisello a semina autunnale e primaverile. Agricoltura 9:107-11.

Degussa AG, 2006. Amino Dat 3.0. The amino acid composition of feed- 
stuffs. 5th rev. ed. Degussa AG, Feed Additives, Hanau, Germany.

Duzdemir 0, Ece A, 2011. Determining relationships among plant characteristics related to plant seed yield of broad bean (Vicia faba L.) sown in winter and summer seasons in transitional climate areas of Turkey. Bulgarian J. Agri. Sci. 17:73-82.

European Commission, 2007. Council Regulation (EC) No 834/2007 of 28 June 2007 on organic production and labelling of organic products and repealing Regulation (EEC) No 2092/91. In: Official Journal, L 189, 20/7/2007, pp 1-23.

European Commission, 2008. Commission Regulation (EC) No 889/2008 of 5 September 2008 laying down detailed rules for the implementation of Council Regulation (EC) No 834/2007 on organic production and labelling of organic products with regard to organic production, labelling and control. In: Official Journal, L 250, 18/9/2008, pp 1-84.

European Commission, 2012. Commission Implementing Regulation (EU) No 505/2012 of 14 June 2012 amending and correcting Regulation (EC) No 889/2008 laying down detailed rules for the implementation of Council Regulation (EC) No 834/2007 on organic production and labelling of organic products with regard to organic production, labelling and control. In: Official Journal, L 154, 15/6/2012, pp 12-9.

Fagnano M, Bozzini A, 2001. Lupino. In: P. Ranalli (ed.) Leguminose e agricoltura sostenibile. Calderini Ed., Bologna, Italy, pp 591-614.

Foti S, 1989. Fava (Vicia faba L. o Faba vulgaris Moench). In: R. Baldoni and L. Giardini (eds.) Coltivazioni erbacee, 2nd ed. Patròn Ed., Bologna, Italy, pp 295-309.

Foti S, Cosentino S, Mauromicale G, 2001. Esigenze ambientali rispetto al clima, al terreno, all'alimentazione. In: P. Ranalli (ed.) Leguminose e agricoltura sostenibile. Calderini Ed., Bologna, Italy, pp 17-43.

Frenda AS, Ruisi P, Saia S, Frangipane B, Di Miceli G, Amato G, Giambalvo $\mathrm{D}, 2013$. The critical period of weed control in faba bean and chickpea in Mediterranean areas. Weed Sci. 61:452-9.

Froidmont E, Bartiaux-Thill N, 2004. Suitability of lupin and pea seeds as a substitute for soybean meal in high-producing dairy cow feed. Animal Res. 53:475-87.

Husain MM, Hill GD, Gallagher JN, 1988. The response of field beans (Vicia faba L.) to irrigation and sowing date: 1. Yield and yield components. J. Agri. Sci. 111:221-32.

Innocenti A, Dal Re L, 2007. Il lupino bianco, leguminosa interessante. Agricoltura 1:68-9.

Jensen ES, Peoples MB, Hauggaard-Nielsen H, 2010. Faba bean in cropping systems. Field Crops Res. 115:203-16.

Jezierny D, Mosenthin R, Bauer E, 2010. The use of grain legumes as a protein source in pig nutrition: a review. Animal Feed Sci. Technol. 157:111-28.

Jezierny D, Mosenthin R, Eklund M, Rademacher M, 2007. Determination of standardized ideal digestibilities of crude protein and amino acids in legume seeds for growing pigs. pp 198- 203 in Proc. 16th Int. Sci. Symp. on Nutrition of Domestic Animals, Radenci, Slovenia.

Köpke U, Nemecek T, 2010. Ecological services of faba bean. Field Crops Res. 115:217-33.

Lundkvist A, 2009. Effects of pre- and post-emergence weed harrowing on annual weeds in peas and spring cereals. Weed Res. 49:409-16.

Mipaaf, 2012a. Bioreport. 2012. L'agricoltura biologica in Italia. Rete Rurale Nazionale 2007-2013. Ministero delle Politiche Agricole e Forestali, Roma, Italy.

Mipaaf, 2012b. Catalogo delle varietà delle specie di piante agricole - Anno 2012. Ministero delle Politiche Agricole e Forestali, Roma, Italy.

Monotti M, Stagnari F, Conti D, Petrini A, Cappelli S, Cocchiarella AG, Raggi V, Gargano E, Orfei M, Quattrucci M, 2004. Valutazione di varietà di pisello proteico e di favino in ambienti centro-meridionali. Informatore Agrario 39:67-72.
Mordenti A, De Castro P, 2005. Mangimi gm e produzioni tipiche, una convivenza forzata. Informatore Agrario 14:47-50.

Nowack HK, Bickel R, Pushparajah LR, Wyss E, 2002. Sicherung der gentechnikfreien Produktion. Eintrittswege gentechnisch veränderter Organismen, Gegenmassnahmen und Empfehlungen. Federal Office for the Environment, Forests and Landscape (UFAFP), n. 340.

Pang XP, Letey J, 2000. Organic farming: challenge of timing nitrogen availability to crop nitrogen requirements. Soil Sci. Soc. Am. J. 64:247-53.

Pielou EC, 1966. Shannon's formula as a measure of species diversity: its use and misure. Amer. Naturalist 100:463-5.

PLSR, 2009. Programma Locale di Sviluppo Rurale. Provincia di Firenze, Comunità Montana del Mugello, Comunità Montana montagna fiorentina. Programma di Sviluppo Rurale Regione Toscana 20072013, pp 19-22.

Postiglione L, 1986. Influenza dell'epoca di semina sul comportamento biologico e produttivo di cultivar di lupino povere di alcaloidi. Agricoltura e Ricerca 55:69-74.

Ranalli P, 2001. Leguminose e agricoltura sostenibile. Specie da granella e da cover crops. Calderini Ed., Bologna, Italy, pp 591-614.

Ranalli P, Parisi B, 2001. Chapter 14 - Pisello (Pisum sativum L.). Leguminose e agricoltura sostenibile. Specie da granella e da cover crops. Calderini Ed., Bologna, Italy, pp 503-554.

Sanesi G, 1977. I suoli del bacino dei torrenti Diaterna e lineamenti pedologici del Mugello e dell'alta valle del Santerno, Firenze. CNR, Centro di studio per la genesi, classificazione e cartografia del suolo. G. Capponi, Firenze, Italy, p 96.

Shannon CE, Weaver W, 1963. The mathematical theory of communication. University of Illinois Press, Urbana, IL, USA, p 117.

Siddique KHM, Loss SP, Reagan KL, Jettner RL, 1999. Adaptation and seed yield of cool season grain legumes in the mediterranean environments of south - western Australia. Austr. J. Agric. Res. 50:375-88.

SINAB 2013. Bio in cifre 2012. Sistema d'informazione nazionale sull'agricoltura biologica. Ministero delle Politiche Agricole Alimentari e Forestali, Roma, Italy.

Stock HG, 1977. Preliminary results obtained from studies into temporally differentiated water supply to field bean and its effects in term of yield formation. TagBer. Dt Akad LandWiss. Berl. 158:229-41.

Stringi L, 1994. Acquisizioni e prospettive di sviluppo nella tecnica colturale della fava da granella (Vicia faba L.). Agricoltura e Ricerca 155:31-46.

Tavoletti S, Mattii S, Pasquini M, Trombetta MF, 2004. La reintroduzione delle colture proteiche nelle filiere agro zootecniche marchigiane. Informatore Agrario 21:31-4.

Unkovich MJ, Pate JS, 2000. An appraisal for recent field measurements of symbiotic N2 fixation by annual legumes. Field Crops Res. 65:211-28.

Unkovich MJ, Pate JS, Sanford P, 1997. Nitrogen fixation by annual legumes in Australian Mediterranean agriculture. Austr. J. Agric. Res. 48:267-93.

Van Kessel C, Hartley C, 2000. Agricultural management of grain legumes: has it led to an increase in nitrogen fixation?. Field Crops Res. 65:165-81.

Van Soest PJ, Robertson JB, Lewis BA, 1991. Methods for dietary fiber, neutral detergent fiber, and non starch polysaccharides in relation to animal nutrition. J. Dairy Sci. 74:3583-97.

Willer H, Lernoud J, Kilcher L, 2013. The world of organic agriculture. Statistics and emerging trends 2013. Research Institute of Organic Agriculture (FiBL), Frick and International Federation of Organic Agriculture Movements (IFOAM), Bonn, Germany. 